\title{
Mathematical model of gas-dynamic and thermal processes in a steam turbine *
}

\author{
A.I. Sukhinov, A.E. Chistyakov**, N.N. Efimov, V.N. Baltyan*** \\ Don State Technical University, Rostov-on-Don, Russia \\ Platov South-Russian State Polytechnic University (NPI), Novocherkassk, Russia
}

The paper covers the calculation of aerodynamic processes in a steam turbine using modern information technology and computational methods for improving the calculation accuracy. The practical significance of the paper is the next: the model of aerodynamic processes in the steam turbine is developed and implemented; limits and prospects of the proposed mathematical model is defined. Aerodynamic processes in the turbine are characterized by uneven steam and heat flows, which significantly affect the reliability and efficiency of the turbine. The calculation was performed taking into account the complex geometry of the turbine and can be applied to any turbine of similar design with minor changes.

Keywords: mathematical model; aerodynamics; steam turbine; computational experiments, steam and heat flows

Introduction. The question about the optimization problem of installation and exploitation of steam tur-bines is the actual. Strict requirements are imposed on the development of modern technologies and industry needs to operate the turbines, associated with the reliability and efficiency of their operation. At present, it is necessary to put into operation more modern turbogenerators to replace physically and technically obsolete units. Design of steam turbines is carried out on the basis of the theory of gas dynamics, taking into account the results of analysis of heat exchange processes, which allow to assess the reliability and efficiency of installation. Modeling of such complex systems is the problem of optimal control of thermal conditions, which allows choosing the best from different implementations. Optimization of thermal conditions is reduced to solving the problem of thermal conductivity. Mathematical modeling of gas-dynamic and thermal processes in technogenic systems is the relevant, due to which the correctness of accepted engineering ideas can be check and correct errors at the design stage using simple and inexpensive means. After the design stage, it is necessary to determine the real temperature values at significant points of the steam facility and analyze the compliance with required values.

Problem Statement. The main equations of gas dynamics of operating environment are:

- the Navier-Stokes system of equations

\footnotetext{
${ }^{*}$ The paper is carried out within the framework of the agreement with the Ministry of education and science of the Russian Federation No. № 14.577.21.0260 on the provision of subsidies from 26.09.2017, the Federal target program «Research and development in priority areas of the scientific and technological complex of Russia for 2014-2020».

** E-mail: sukhinov@gmail.com, cheese_05@mail.ru.

*** E-mail: efimov@novoch.ru.
} 


$$
\begin{aligned}
& \frac{\partial v_{x}}{\partial t}+v_{x} \frac{\partial v_{x}}{\partial x}+v_{y} \frac{\partial v_{x}}{\partial y}+v_{z} \frac{\partial v_{x}}{\partial z}=-\frac{1}{\rho} \frac{\partial P}{\partial x}+\mu\left(\frac{\partial^{2} v_{x}}{\partial x^{2}}+\frac{\partial^{2} v_{x}}{\partial y^{2}}+\frac{\partial^{2} v_{x}}{\partial z^{2}}\right)+f_{x}, \\
& \frac{\partial v_{y}}{\partial t}+v_{x} \frac{\partial v_{y}}{\partial x}+v_{y} \frac{\partial v_{y}}{\partial y}+v_{z} \frac{\partial v_{y}}{\partial z}=-\frac{1}{\rho} \frac{\partial P}{\partial y}+\mu\left(\frac{\partial^{2} v_{y}}{\partial x^{2}}+\frac{\partial^{2} v_{y}}{\partial y^{2}}+\frac{\partial^{2} v_{y}}{\partial z^{2}}\right)+f_{y}, \\
& \frac{\partial v_{z}}{\partial t}+v_{x} \frac{\partial v_{z}}{\partial x}+v_{y} \frac{\partial v_{z}}{\partial y}+v_{z} \frac{\partial v_{z}}{\partial z}=-\frac{1}{\rho} \frac{\partial P}{\partial z}+\mu\left(\frac{\partial^{2} v_{z}}{\partial x^{2}}+\frac{\partial^{2} v_{z}}{\partial y^{2}}+\frac{\partial^{2} v_{z}}{\partial z^{2}}\right)+f_{z},
\end{aligned}
$$

- the continuity equation

$$
\rho_{t}^{\prime}+(\rho u)_{x}^{\prime}+(\rho v)_{y}^{\prime}+(\rho w)_{z}^{\prime}=0
$$

- the condition equation

$$
P=\varepsilon \frac{\rho}{M} R T,
$$

where $\mathbf{V}=\left\{v_{x}, v_{y}, v_{z}\right\}$ are velocity vector component values; $P$ is the pressure; $\rho$ is the density; $M$ is the molar mass; $R$ is the universal gas constant; $\mu$ is the turbulent exchange coefficient; $T$ is the temperature; $\varepsilon$ is a coefficient, describing the deviation of the superheated steam pressure from the ideal gas.

Let us assume that the operating environment is initially at rest. Thus, the initial conditions are following: $u=0, w=0, P=P_{a}$, where $P_{a}$ is the initial pressure.

The system of equations (1), (2) is considered under the following boundary conditions:

- on the impenetrable boundary

$$
\rho_{w} \eta \frac{\partial v_{x}}{\partial n}=\tau_{x, b}(t), \rho_{w} \eta \frac{\partial v_{y}}{\partial n}=\tau_{y, b}(t), \rho_{w} \eta \frac{\partial v_{z}}{\partial n}=\tau_{z, b}(t), \mathbf{V}_{n}=0, P_{n}^{\prime}=0
$$

- on the side permeable boundary $\frac{\partial v_{x}}{\partial n}=0, \frac{\partial v_{y}}{\partial n}=0, \frac{\partial v_{z}}{\partial n}=0, \frac{\partial P}{\partial n}=0$;

- on the source $v_{x}=U, v_{y}=V, v_{z}=W, \frac{\partial P}{\partial n}=0 ;$

where $U, V, W$ are the velocity vector components on the source; $\tau_{x}, \tau_{z}$ are the components of tangential shear stress.

The Navier-Stocks system of equations (1) in the cylindrical coordinate system will take the form: $\quad \frac{\partial v_{r}}{\partial t}+v_{r} \frac{\partial v_{r}}{\partial r}+\frac{v_{\theta}}{r} \frac{\partial v_{r}}{\partial \theta}-\frac{v_{\theta}^{2}}{r}+v_{z} \frac{\partial v_{r}}{\partial z}=-\frac{1}{\rho} \frac{\partial P}{\partial r}+\mu\left(\frac{\partial}{\partial r}\left(\frac{1}{r} \frac{\partial\left(r v_{r}\right)}{\partial r}\right)+\frac{1}{r^{2}} \frac{\partial^{2} v_{r}}{\partial \theta^{2}}-\frac{2}{r^{2}} \frac{\partial v_{\theta}}{\partial \theta}+\frac{\partial^{2} v_{r}}{\partial z^{2}}\right)+f_{r}$,

$$
\begin{gathered}
\frac{\partial v_{\theta}}{\partial t}+v_{r} \frac{\partial v_{\theta}}{\partial r}+\frac{v_{\theta}}{r} \frac{\partial v_{\theta}}{\partial \theta}+\frac{v_{\theta} v_{r}}{r}+v_{z} \frac{\partial v_{\theta}}{\partial z}=-\frac{1}{r \rho} \frac{\partial P}{\partial \theta}+\mu\left(\frac{\partial}{\partial r}\left(\frac{1}{r} \frac{\partial\left(r v_{\theta}\right)}{\partial r}\right)+\frac{1}{r^{2}} \frac{\partial^{2} v_{\theta}}{\partial \theta^{2}}+\frac{2}{r^{2}} \frac{\partial v_{r}}{\partial \theta}+\frac{\partial^{2} v_{\theta}}{\partial z^{2}}\right)+f_{\theta}, \\
\frac{\partial v_{z}}{\partial t}+v_{r} \frac{\partial v_{z}}{\partial r}+\frac{v_{\theta}}{r} \frac{\partial v_{z}}{\partial \theta}+v_{z} \frac{\partial v_{z}}{\partial z}=-\frac{1}{\rho} \frac{\partial P}{\partial z}+\mu\left(\frac{1}{r} \frac{\partial}{\partial r}\left(r \frac{\partial v_{z}}{\partial r}\right)+\frac{1}{r^{2}} \frac{\partial^{2} v_{z}}{\partial \theta^{2}}+\frac{\partial^{2} v_{z}}{\partial z^{2}}\right)+f_{z} .
\end{gathered}
$$

The position of a point in cylindrical coordinate system is determined by the numbers $r, \theta, z$. 
The system of equations (4) in the case of axial symmetry has the form:

$$
\begin{gathered}
\frac{\partial v_{r}}{\partial t}+v_{r} \frac{\partial v_{r}}{\partial r}-\frac{v_{\theta}^{2}}{r}+v_{z} \frac{\partial v_{r}}{\partial z}=-\frac{1}{\rho} \frac{\partial P}{\partial r}+\mu\left(\frac{\partial}{\partial r}\left(\frac{1}{r} \frac{\partial\left(r v_{r}\right)}{\partial r}\right)+\frac{\partial^{2} v_{r}}{\partial z^{2}}\right)+f_{r}, \\
\frac{\partial v_{\theta}}{\partial t}+v_{r} \frac{\partial v_{\theta}}{\partial r}+\frac{v_{\theta} v_{r}}{r}+v_{z} \frac{\partial v_{\theta}}{\partial z}=\mu\left(\frac{\partial}{\partial r}\left(\frac{1}{r} \frac{\partial\left(r v_{\theta}\right)}{\partial r}\right)+\frac{\partial^{2} v_{\theta}}{\partial z^{2}}\right)+f_{\theta}, \\
\frac{\partial v_{z}}{\partial t}+v_{r} \frac{\partial v_{z}}{\partial r}+v_{z} \frac{\partial v_{z}}{\partial z}=-\frac{1}{\rho} \frac{\partial P}{\partial z}+\mu\left(\frac{1}{r} \frac{\partial}{\partial r}\left(r \frac{\partial v_{z}}{\partial r}\right)+\frac{\partial^{2} v_{z}}{\partial z^{2}}\right)+f_{z} .
\end{gathered}
$$

The continuity equation (2) in the cylindrical coordinate system has the form:

$$
\frac{\partial \rho}{\partial t}+\frac{1}{r} \frac{\partial\left(\rho r v_{r}\right)}{\partial r}+\frac{1}{r} \frac{\partial\left(\rho v_{\theta}\right)}{\partial \theta}+\frac{\partial\left(\rho v_{z}\right)}{\partial z}=0,
$$

The equation (5) in the case of axial symmetry takes the form:

$$
\frac{\partial \rho}{\partial t}+\frac{1}{r} \frac{\partial\left(\rho r v_{r}\right)}{\partial r}+\frac{\partial\left(\rho v_{z}\right)}{\partial z}=0 \text {. }
$$

Condition equation. The equation of the specific Gibbs energy is the main for superheated steam. Its consist of two parts, relating to the ideal gas condition $\gamma^{0}$ and describing the real component $\gamma^{r}:$

$$
\begin{aligned}
g(\mathrm{p}, \mathrm{T}) / \mathrm{RT} & =\gamma(\pi, \tau)=\gamma^{0}(\pi, \tau)+\gamma^{r}(\pi, \tau) \\
\gamma^{0} & =\ln \pi+\sum_{i=1}^{9} n_{i}^{0} \tau^{J_{i}^{0}} \\
\gamma^{r} & =\sum_{i=1}^{43} n_{i} \pi^{I_{i}}(\tau-0,5)^{J_{i}}
\end{aligned}
$$

where $\pi=p / p^{*}$ and $\tau=T^{*} / T ; p^{*}=1 M P a$ and $T^{*}=540 \mathrm{~K}$. The coefficients and exponents for the equation (8) are given in the Table 2 , and for the equation (9) - in the Table 3.

Table 1. Relations for calculation the thermodynamic properties by the equation (7)

\begin{tabular}{ll}
\hline Characteristic & Ratio \\
\hline Specific volume & $v P / R T=\pi \gamma_{\pi}$ \\
Specific internal energy & $u / R T=\tau \gamma_{\tau}-\pi \gamma_{\pi}$ \\
Specific entropy & $s / R=\tau \gamma_{\tau}-\gamma$ \\
Specific enthalpy & $h / R T=\tau \gamma_{\tau}$ \\
Specific isobaric heat capacity & $c_{p} / R=-\tau^{2} \gamma_{\tau \tau}$ \\
Specific isochoric heat capacity & $c_{v} / R=-\tau^{2} \gamma_{\tau \tau}+\left(\gamma_{\pi}-\tau \gamma_{\pi \tau}\right)^{2} / \gamma_{\pi \pi}$ \\
& $w^{2} / R T=\gamma_{\pi}^{2} /\left(\frac{\left(\gamma_{\pi}-\tau \gamma_{\pi \tau}\right.}{\tau^{2} \gamma_{\tau \tau}}-\gamma_{\pi \pi}\right)$ \\
\hline
\end{tabular}


In the Table 1:

$$
\gamma_{\pi}=\left(\frac{\partial \gamma}{\partial \pi}\right)_{\tau} ; \gamma_{\pi \pi}=\left(\frac{\partial^{2} \gamma}{\partial \pi^{2}}\right)_{\tau} ; \gamma_{\tau}=\left(\frac{\partial \gamma}{\partial \tau}\right)_{\pi} ; \gamma_{\tau \tau}=\left(\frac{\partial^{2} \gamma}{\partial \tau^{2}}\right)_{\pi} ; \gamma_{\pi \tau}=\left(\frac{\partial^{2} \gamma}{\partial \pi \partial \tau}\right) .
$$

According to the ratio for the relative volume:

$$
\begin{gathered}
P M=\pi \gamma_{\pi} \rho R T=\left(1+\sum_{i=1}^{43} n_{i} I_{i} \pi^{I_{i}}(\tau-0,5)^{J_{i}}\right) \rho R T \text { or } \\
P M=\left(1+\sum_{i=1}^{43} n_{i} I_{i}\left(p / p^{*}\right)^{I_{i}}\left(T^{*} / T-0,5\right)^{J_{i}}\right) \rho R T .
\end{gathered}
$$

Table 2. Coefficients and exponents for the equation (8)

\begin{tabular}{|c|c|c|c|c|c|}
\hline$i$ & $J_{i}^{0}$ & $n_{i}^{0}$ & $i$ & $J_{i}^{0}$ & $n_{i}^{0}$ \\
\hline 1 & 0 & $-0,969 \cdot 10^{1}$ & 6 & -2 & $0,142 \cdot 10^{1}$ \\
\hline 2 & 1 & $0,100 \cdot 10^{2}$ & 7 & -1 & $-0,438 \cdot 10^{1}$ \\
\hline 3 & -5 & $-0,560 \cdot 10^{-2}$ & 8 & 2 & $-0,284$ \\
\hline 4 & -4 & $0,714 \cdot 10^{-1}$ & 9 & 3 & $0,212 \cdot 10^{-1}$ \\
\hline 5 & -3 & $-0,40728$ & 6 & -2 & $0,142 \cdot 10^{1}$ \\
\hline
\end{tabular}

Table 3. Coefficients and exponents for the equation (9)

\begin{tabular}{|l|l|l|l|l|l|l|l|l|l|l|l|}
\hline$i$ & $I_{i}$ & $J_{i}$ & $n_{i}$ & $i$ & $I_{i}$ & $J_{i}$ & $n_{i}$ & $i$ & $I_{i}$ & $J_{i}$ & $n_{i}$ \\
\hline 1 & 1 & 0 & $-0,177 \cdot 10^{-2}$ & 16 & 4 & 1 & $-0,788 \cdot 10^{-9}$ & 31 & 10 & 14 & $-0,100 \cdot 10^{-8}$ \\
\hline 2 & 1 & 1 & $-0,178 \cdot 10^{-1}$ & 17 & 4 & 2 & $0,127 \cdot 10^{-7}$ & 32 & 16 & 29 & $-0,808 \cdot 10^{-10}$ \\
\hline 3 & 1 & 2 & $-0,459 \cdot 10^{-1}$ & 18 & 4 & 3 & $0,482 \cdot 10^{-6}$ & 33 & 16 & 50 & 0,106 \\
\hline 4 & 1 & 3 & $-0,575 \cdot 10^{-1}$ & 19 & 5 & 7 & $0,229 \cdot 10^{-5}$ & 34 & 18 & 57 & $-0,336$ \\
\hline 5 & 1 & 6 & $-0,503 \cdot 10^{-1}$ & 20 & 6 & 3 & $-0,167 \cdot 10^{-10}$ & 35 & 20 & 20 & $0,891 \cdot 10^{-24}$ \\
\hline 6 & 2 & 1 & $-0,330 \cdot 10^{-4}$ & 21 & 6 & 16 & $-0,211 \cdot 10^{-2}$ & 36 & 20 & 35 & $0,306 \cdot 10^{-12}$ \\
\hline 7 & 2 & 2 & $-0,189 \cdot 10^{-3}$ & 22 & 6 & 35 & $-0,238 \cdot 10^{2}$ & 37 & 20 & 48 & $-0,420 \cdot 10^{-5}$ \\
\hline 8 & 2 & 4 & $-0,393 \cdot 10^{-2}$ & 23 & 7 & 0 & $-0,590 \cdot 10^{-17}$ & 38 & 21 & 21 & $-0,590 \cdot 10^{-25}$ \\
\hline 9 & 2 & 7 & $-0,437 \cdot 10^{-1}$ & 24 & 7 & 11 & $-0,126 \cdot 10^{-5}$ & 39 & 22 & 53 & $0,378 \cdot 10^{-5}$ \\
\hline 10 & 2 & 36 & $-0,266 \cdot 10^{-4}$ & 25 & 7 & 25 & $-0,389 \cdot 10^{-1}$ & 40 & 23 & 39 & $-0,127 \cdot 10^{-14}$ \\
\hline 11 & 3 & 0 & $0,204 \cdot 10^{-7}$ & 26 & 8 & 8 & $0,112 \cdot 10^{-10}$ & 41 & 24 & 26 & $0,730 \cdot 10^{-28}$ \\
\hline 12 & 3 & 1 & $0,438 \cdot 10^{-6}$ & 27 & 8 & 36 & $-0,823 \cdot 10^{1}$ & 42 & 24 & 40 & $0,554 \cdot 10^{-16}$ \\
\hline 13 & 3 & 3 & $-0,322 \cdot 10^{-4}$ & 28 & 9 & 13 & $0,198 \cdot 10^{-7}$ & 43 & 24 & 58 & $-0,943 \cdot 10^{-6}$ \\
\hline 14 & 3 & 6 & $-0,150 \cdot 10^{-2}$ & 29 & 10 & 4 & $0,104 \cdot 10^{-18}$ & 31 & 10 & 14 & $-0,100 \cdot 10^{-8}$ \\
\hline 15 & 3 & 35 & $-0,406 \cdot 10^{-1}$ & 30 & 10 & 10 & $-0,102 \cdot 10^{-12}$ & 32 & 16 & 29 & $-0,808 \cdot 10^{-10}$ \\
\hline
\end{tabular}

All thermodynamic properties of superheated water steam can also be obtained from equation (7) using differential relations of thermodynamics.

Turbulence Model. Let's use the Abramovich-Secundov model, which takes into account very important factors such as the presence of rigid walls, flow background, convective and diffusion transfer of turbulent fluctuations:

$$
\frac{\partial v_{\text {турб }}}{\partial t}+\sum_{i=1}^{3} v_{i} \frac{\partial v_{\text {турб }}}{\partial x_{i}}=\sum_{i=1}^{3} \frac{\partial}{\partial x_{i}}\left(\left(v_{\text {мол }}+k v_{\text {турб }}\right) \frac{\partial v_{\text {турб }}}{\partial x_{i}}\right)+v_{\text {турб }} f\left(\frac{v_{\text {турб }}}{8 v_{\text {мол }}}\right) D-\gamma S,
$$




$$
S=\frac{v_{\text {турб }}\left(v_{\text {мол }}+\beta v_{\text {турб }}\right)}{L_{\min }^{2}}, D=\sqrt{\sum_{i=1}^{3} \sum_{j} \frac{\partial v_{i}}{\partial x_{j}}\left(\frac{\partial v_{i}}{\partial x_{j}}+\frac{\partial v_{j}}{\partial x_{i}}\right)}, f(z)=0,2 \frac{z^{2}+1,47 z+0,2}{z^{2}-1,47 z+1},
$$

where $k=2, \gamma=50, \beta=0,06 ; L_{\min }$ is the minimum distance to a solid wall; $v_{\text {мол }}$ is the molecular viscosity; $v_{\text {тур }}$ is the turbulent viscosity.

The turbulence model (10) is considered under the boundary condition:

$$
\left.\left(v_{\text {mypб }}\right)_{n}^{\prime}(t, x, y, z)\right|_{(x, y, z) \in \Gamma}=0 .
$$

Add the initial condition for the model (1):

$\left(v_{\text {mурб }}\right)(t, x, y, z)=v_{0}$.

The following equation was used for calculation the dynamic viscosity values $v_{\text {мол }}$ :

$$
v_{\text {мол }}=\bar{v}_{0}(\tau) \cdot \bar{v}_{1}(\tau, \delta) \cdot v^{*},
$$

where $v^{*}=55,071 \cdot 10^{-6} \mathrm{~Pa} \cdot \mathrm{sec} ; \tau=T / T^{*} ; T$ is the temperature, $[\mathrm{K}] ; T^{*}=647,226 \mathrm{~K} ; \delta=\rho / \rho^{*} ; \rho$ is the density, $\left[\mathrm{kg} / \mathrm{m}^{3}\right] ; \rho^{*}=317,763 \mathrm{~kg} / \mathrm{m}^{3} ; \bar{v}_{0}=v_{0} / v^{*} ; v_{0}$ is the dynamic viscosity of water steam in the zero density limit.

$$
\bar{v}_{0}(\tau)=\tau^{0,5}\left(\sum_{i=0}^{3} H_{i} \tau^{-i}\right)^{-1},
$$

where $H_{0}=1, H_{1}=0,978197, H_{2}=0,579829, H_{3}=-0,202354$.

$$
\bar{v}_{1}(\tau, \delta)=\exp \left(\delta \sum_{i=0}^{5} \sum_{j=0}^{6} H_{i, j}(1 / \tau-1)^{i}(\delta-1)^{j}\right) .
$$

Coefficients $H_{i, j}$ for this equation are given in the Table 4.

Table 4. Coefficients and exponents for the equation (13)

\begin{tabular}{|l|l|l|l|l|l|l|l|}
\hline $\mathrm{ilj}$ & 0 & 1 & 2 & 3 & 4 & 5 & 6 \\
\hline 0 & 0,513204 & 0,215177 & $-0,281810$ & 0,177806 & $-0,041766$ & - & - \\
\hline 1 & 0,320565 & 0,731788 & $-1,070786$ & 0,460504 & - & $-0,015783$ & - \\
\hline 2 & - & 1,241044 & $-1,263184$ & 0,234037 & - & - & - \\
\hline 3 & - & 1,476783 & - & $-0,492417$ & 0,160043 & - & $-0,003629$ \\
\hline 4 & -0.778256 & - & - & - & - & - & - \\
\hline 5 & 0,188544 & - & - & - & - & - & - \\
\hline
\end{tabular}

The error of the dynamic viscosity at the pressures up to $50 \mathrm{MPa}$ and the temperatures up to $475^{\circ} \mathrm{C}$ is equaled to the $2 \%$, at higher pressures or temperatures $-3 \%$.

Heat conduction problem. Thermal processes in turbine $\bar{G}$ was described by the heat conduction equation:

$$
c \rho \frac{\partial T}{\partial t}+v_{x} \frac{\partial T}{\partial x}+v_{y} \frac{\partial T}{\partial y}+v_{z} \frac{\partial T}{\partial z}=\frac{\partial}{\partial x}\left(\lambda \frac{\partial T}{\partial x}\right)+\frac{\partial}{\partial y}\left(\lambda \frac{\partial T}{\partial y}\right)+\frac{\partial}{\partial z}\left(\lambda \frac{\partial T}{\partial z}\right)+q_{v}(P),
$$

which in the case of axial symmetry can be written as: 


$$
\rho c r T_{t}^{\prime}+r v_{r} T_{r}^{\prime}+r v_{z} T_{z}^{\prime}=r\left(\lambda T_{z}^{\prime}\right)_{z}^{\prime}+\left(\lambda r T_{r}^{\prime}\right)_{r}^{\prime}+r q_{v}(P) .
$$

In the system (14), (15) $T$ is the temperature; $\lambda$ is the conductivity of water; $\rho$ is the metal density; $c$ is the heat capacity of metal; $r$ is the polar radius; $q_{v}(P)$ is the source function. We will consider the equation (15) with the boundary conditions of third kind:

$$
T_{n}^{\prime}(x, r, t)=\alpha_{n} T+\beta_{n},
$$

where $\boldsymbol{n}$ is the normal vector to the $\bar{G}$.

An initial condition were added to the equation (15):

$$
T(x, r, 0)=T_{0}(x, r),(x, r) \in \bar{G} .
$$

The following equation is used to determine the coefficient of thermal conductivity of water and water steam in international practice:

$$
\lambda=\lambda_{0}(\tau)+\lambda_{1}(\delta)+\lambda_{2}(\tau, \delta)
$$

where $\lambda$ is the conductivity; $\mathrm{W} /(\mathrm{m} \cdot \mathrm{K}) ; \tau=T / T^{*} ; T$ is the absolute temperature, $\mathrm{K} ; T^{*}==647,256 \mathrm{~K}$; $\delta=\rho / \rho^{*} ; \rho$ is the density, $\mathrm{kg} / \mathrm{m}^{3} ; \rho^{*}=317,7 \mathrm{~kg} / \mathrm{m}^{3}$. The thermal conductivity of water steam $\lambda_{0}(\tau)$ in the ideal gas condition is determined by the equation:

$$
\begin{gathered}
\lambda_{0}(\tau)=\tau^{0,5} \sum_{\kappa=0}^{3} a_{\kappa} \tau^{\kappa}, \\
a_{0}=0,0102811 ; a_{1}=0,0299621 ; a_{2}=0,0156146 ; a_{3}=-0,00422464 .
\end{gathered}
$$

The function $\lambda_{1}(\delta)$ is defined as: $\lambda_{1}(\delta)=b_{0}+b_{1} \delta+b_{2} \exp \left\{B_{1}\left(\delta+B_{2}\right)^{2}\right\}$, where $b_{0}=-0,397070$; $b_{1}=0,400302 ; b_{2}=1,06000 ; B_{1}=-0,171587 ; B_{2}=2,392190 ;$ and the function $\lambda_{2}(\tau, \delta)$ has the form: $\lambda_{2}(\tau, \delta)=\left(\frac{d_{1}}{10}+d_{2}\right) \delta^{9 / 5} \exp \left[C_{1}\left(1-\delta^{14 / 5}\right)\right]+d_{3} S \delta^{Q} \exp \left[\left(\frac{Q}{1+Q}\right)\left(1-\delta^{1+Q}\right)\right]+d_{4} \exp \left(C_{2} \tau^{3 / 2}+\frac{C_{3}}{\delta^{5}}\right)$, where $Q$ and $S$ are functions of the value $\Delta \tau=|\tau-1|+C_{4}: \quad Q=2+C_{5} / \Delta \tau^{0,6}$; $S= \begin{cases}1 / \Delta \tau & \text { for } \tau \geq 1 \\ C_{6} / \Delta \tau^{0,6} & \text { for } \tau<1\end{cases}$

The coefficients $d_{i}$ and $C_{i}$ have the following values:

$$
\begin{gathered}
d_{1}=0,0701309 ; d_{2}=0,0118520 ; d_{3}=0,00169937 ; d_{4}=-1,0200 ; C_{1}=0,642857 ; \\
C_{2}=-4,11717 ; C_{3}=-6,17937 ; C_{4}=0,00308976 ; C_{5}=0,0822994 ; C_{6}=10,0932 .
\end{gathered}
$$

The equation (14) is applicable with the following temperature and pressure values: $p \leq 100$ $\mathrm{MPa}$ for $0 \leq T \leq 500^{\circ} \mathrm{C} ; p \leq 70 \mathrm{MPa}$ for $500<T \leq 650^{\circ} \mathrm{C} ; p \leq 40 \mathrm{MPa}$ for $650<T \leq 800^{\circ} \mathrm{C}$.

The error values in the liquid at temperatures $25-200{ }^{\circ} \mathrm{C}$ and pressures up to $5 \mathrm{MPa}$ is equaled to the $1.5 \%$ in the calculations, at higher temperatures up to $300{ }^{\circ} \mathrm{C}-2 \%$. The error is equaled to the $1.5 \%$ at temperatures up to $550{ }^{\circ} \mathrm{C}$ and the pressure of $0.1 \mathrm{MPa}$ for the water steam, at pressures up to $40 \mathrm{MPa}-3 \%$. The equation (18), in comparison with the theoretical conclusions, determines the not infinite, but the final value of the thermal conductivity coefficient at the critical point, which does not allow estimating the error value near its critical point. 
Splitting schemes into physical processes. According to the pressure correction method [14], the initial model of aerodynamics (1)-(3) is devided into three subtasks. The first subtask was represented by the diffusion-convection equation, on the basis of which the velocity field was calculated at the intermediate time step:

$$
\begin{gathered}
\frac{\tilde{v}_{r}-v_{r}}{\tau}+v_{r} \frac{\partial v_{r}}{\partial r}-\frac{v_{\theta}^{2}}{r}+v_{z} \frac{\partial v_{r}}{\partial z}=\mu\left(\frac{\partial}{\partial r}\left(\frac{1}{r} \frac{\partial\left(r v_{r}\right)}{\partial r}\right)+\frac{\partial^{2} v_{r}}{\partial z^{2}}\right)+f_{r}, \\
\frac{\hat{v}_{\theta}-v_{\theta}}{\tau}+v_{r} \frac{\partial v_{\theta}}{\partial r}+\frac{v_{\theta} v_{r}}{r}+v_{z} \frac{\partial v_{\theta}}{\partial z}=\mu\left(\frac{\partial}{\partial r}\left(\frac{1}{r} \frac{\partial\left(r v_{\theta}\right)}{\partial r}\right)+\frac{\partial^{2} v_{\theta}}{\partial z^{2}}\right)+f_{\theta}, \\
\frac{\tilde{v}_{z}-v_{z}}{\tau}+v_{r} \frac{\partial v_{z}}{\partial r}+v_{z} \frac{\partial v_{z}}{\partial z}=\mu\left(\frac{1}{r} \frac{\partial}{\partial r}\left(r \frac{\partial v_{z}}{\partial r}\right)+\frac{\partial^{2} v_{z}}{\partial z^{2}}\right)+f_{z} .
\end{gathered}
$$

The calculation of the pressure distribution (the second subtask):

$$
r \frac{\partial \rho}{\partial t}+\frac{\partial\left(\rho r \tilde{v}_{r}\right)}{\partial r}+r \frac{\partial\left(\rho \tilde{v}_{z}\right)}{\partial z}=\tau \frac{\partial}{\partial r}\left(r \frac{\partial P}{\partial r}\right)+\tau r \frac{\partial^{2} P}{\partial z^{2}}
$$

or with taking into account the condition equation

$$
r \frac{\partial(P M / \varepsilon R T)}{\partial t}+\frac{\partial\left(\rho r \tilde{v}_{r}\right)}{\partial r}+r \frac{\partial\left(\rho \tilde{v}_{z}\right)}{\partial z}=\tau \frac{\partial}{\partial r}\left(r \frac{\partial P}{\partial r}\right)+\tau r \frac{\partial^{2} P}{\partial z^{2}} .
$$

A simplified hydrostatic model of the operation environment medium motion was used as an initial approximation for this task. So, the calculation time was significantly reduced.

The distribution of steam velocities on the upper time layer using explicit formulas can be obtained in the third subtask.

$$
\frac{\hat{v}_{r}-\tilde{v}_{r}}{\tau}=-\frac{1}{\rho} \frac{\partial P}{\partial r}, \frac{\hat{v}_{z}-\tilde{v}_{z}}{\tau}=-\frac{1}{\rho} \frac{\partial P}{\partial z} .
$$

where $\tau$ is a the step at the time coordinate; $v$ is the value of the velocity field at the previous time layer; $\tilde{v}$ is the value of the velocity field at the intermediate time layer; $\hat{v}$ is the value of the velocity field at the current time layer.

Difference scheme for the solution of the diffusion-convection problem at high Peclet numbers. Let's consider the two-dimensional convection-diffusion equation:

$$
\frac{\partial q}{\partial t}+u \frac{\partial q}{\partial x}+v \frac{\partial q}{\partial y}=\mu \frac{\partial^{2} q}{\partial x^{2}}+\mu \frac{\partial^{2} q}{\partial y^{2}}
$$

where $t \in[0, T], \quad x \in\left[0, L_{x}\right], \quad y \in\left[0, L_{y}\right] \quad q(0, x, y)=q^{0}(x, y), \quad q(t, 0, y)=q\left(t, L_{x}, y\right)=0$, $q(t, x, 0)=q\left(t, x, L_{y}\right)=0$.

The estimated domain was covered by an uniform computational grid $\omega=\omega_{\tau} \times \bar{\omega}_{x} \times \bar{\omega}_{y}$, where $\bar{\omega}_{x}=\left\{x_{i} \mid x_{i}=i h_{x}, i=0,1, \ldots, N, N h_{x}=L_{x}\right\}, \quad \bar{\omega}_{y}=\left\{y_{i} \mid y_{i}=i h_{y}, i=0,1, \ldots, N, N h_{y}=L_{y}\right\}, \quad \omega_{\tau}=\left\{t_{j} \mid j=0,1, \ldots\right\}$, $\tau=t_{n+1}-t_{n}=$ const .

The splitting scheme for the equation (23) at space will have the form: 


$$
\begin{gathered}
\frac{q_{i, j}^{n+1 / 2}-q_{i, j}^{n}}{\tau}+\psi_{x L} \frac{q_{i-1, j}^{n-1 / 2}-q_{i-1, j}^{n-1}}{2 \tau}+\psi_{x R} \frac{q_{i+1, j}^{n-1 / 2}-q_{i+1, j}^{n-1}}{2 \tau}+ \\
+u \frac{q_{i+1, j}^{n}-q_{i-1, j}^{n}}{4 h_{x}}+\psi_{x L} u \frac{q_{i, j}^{n}-q_{i-1, j}^{n}}{h_{x}}+\psi_{x R} u \frac{q_{i+1, j}^{n}-q_{i, j}^{n}}{h_{x}}=\frac{3}{2} \mu \frac{q_{i+1, j}^{n}-2 q_{i, j}^{n}+q_{i-1, j}^{n}}{h_{x}^{2}} ; \\
\frac{q_{i, j}^{n+1}-q_{i, j}^{n+1 / 2}}{\tau}+\psi_{y L} \frac{q_{i, j-1}^{n}-q_{i, j-1}^{n-1 / 2}}{2 \tau}+\psi_{y R} \frac{q_{i, j+1}^{n}-q_{i, j+1}^{n-1 / 2}}{2 \tau}+ \\
+v \frac{q_{i, j+1}^{n+1 / 2}-q_{i, j-1}^{n+1 / 2}}{4 h_{y}}+\psi_{y L} v \frac{q_{i, j}^{n+1 / 2}-q_{i, j-1}^{n+1 / 2}}{h_{y}}+\psi_{y R} v \frac{q_{i, j+1}^{n+1 / 2}-q_{i, j}^{n+1 / 2}}{h_{y}}=\frac{3}{2} \mu \frac{q_{i, j+1}^{n+1 / 2}-2 q_{i, j}^{n+1 / 2}+q_{i, j-1}^{n+1 / 2}}{h_{y}^{2}},
\end{gathered}
$$

where $\psi_{x L}=1, \psi_{x R}=0$ at $u>0$, and $\psi_{x L}=0, \psi_{x R}=1$ at $u<0 ; \psi_{y L}=1, \psi_{y R}=0$ at $v>0$, and $\psi_{y L}=0, \psi_{y R}=1$ at $v<0$.

The simulation was performed on the grid by the size of $100 \times 100$ computational nodes; the parameters were defined as follows: the dimensions of the computational domain are $L_{x}=100 \mathrm{~m}$, $L_{y}=100 \mathrm{~m}$; the horizontal component is equaled to the $4 \mathrm{~m} / \mathrm{sec}$, the vertical component is equaled to the $3 \mathrm{~m} / \mathrm{sec}$; the turbulent exchange coefficient is equal to the $0,0.1,0.4,2 \mathrm{~m}^{2} / \mathrm{sec}$. The initial distribution was set by the following function at solving the two-dimensional convection-diffusion problem [11-16]:

$$
q(x, y)=\left\{\begin{array}{l}
\sin (\pi(x-10) / 10) \sin (\pi(y-10) / 10),\{x, y\} \in D, D:\{x \in[10,20], y \in[10,20]\}, \\
0,(x, y) \notin D .
\end{array}\right.
$$

Numerical solutions of the convection-diffusion problem at different Peclet numbers using the «cabaret» scheme and the modified scheme (24) are shown in fig. 1.
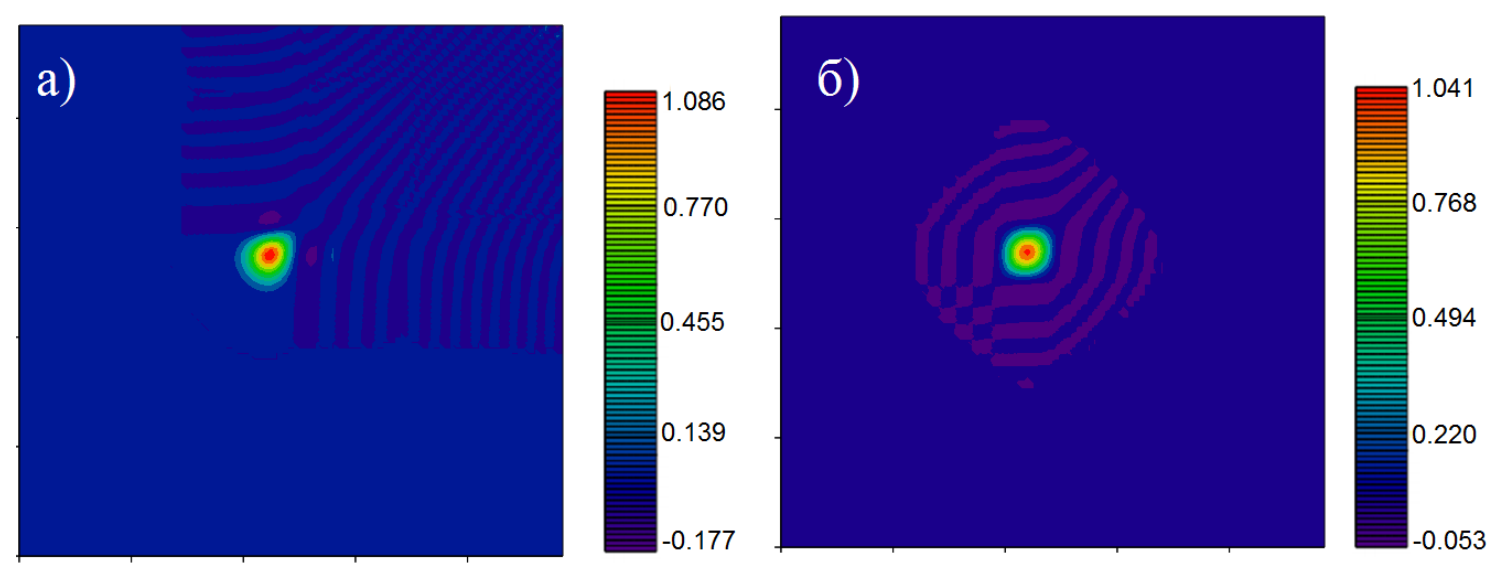

Fig. 1. Numerical solution of the convection problem based on:

a) the «cabaret» scheme, b) the modified scheme

Discrete Model of Aerodynamics. The estimated domain inscribed in a rectangle. A uniform mesh is introduced for the numerical realization of the discrete mathematical model of the problem in the form:

$$
w_{h}=\left\{t^{n}=n \tau, r_{i}=i h_{r}, z_{j}=j h_{z} ; n=\overline{0, N_{t}}, i=\overline{0, N_{r}}, j=\overline{0, N_{z}} ;\right.
$$




$$
\left.N_{t} \tau=l_{t}, N_{r} h_{r}=l_{r}, N_{z} h_{z}=l_{z}\right\},
$$

where $\tau$ is the time step; $h_{r}, h_{z}$ are space steps; $N_{t}$ is the upper time bound; $N_{r}, N_{z}$ are space bounds.

To improve the discrete «smoothness» solution we assume that the cell are not completely filled. [17-22]. The domain $\Omega_{r z}$ is the filled part of the domain $D_{r z} \in\left\{r \in\left[r_{i-1 / 2}, r_{i+1 / 2}\right], z \in\left[z_{j-1 / 2}, z_{j+1 / 2}\right]\right\}$.

We introduced the notation for the following domains:

$$
\begin{aligned}
& D_{1} \in\left\{r \in\left[r_{i}, r_{i+1 / 2}\right], z \in\left[z_{j-1 / 2}, z_{j+1 / 2}\right]\right\} ; D_{2} \in\left\{r \in\left[r_{i-1 / 2}, r_{i}\right], z \in\left[z_{j-1 / 2}, z_{j+1 / 2}\right]\right\}, \\
& D_{3} \in\left\{r \in\left[r_{i-1 / 2}, r_{i+1 / 2}\right], z \in\left[z_{j}, z_{j+1 / 2}\right]\right\} ; D_{4} \in\left\{r \in\left[r_{i-1 / 2}, r_{i+1 / 2}\right], z \in\left[z_{j-1 / 2}, z_{j}\right]\right\} .
\end{aligned}
$$

The occupancy coefficients $q_{0}, q_{1}, q_{2}, q_{3}, q_{4}$, for the domains $D_{r z}, D_{1}, D_{2}, D_{3}, D_{4}$ are introduced as the following: $q_{0}=\frac{S_{D_{r z}}}{S_{\Omega_{r z}}} ; q_{i}=\frac{S_{D_{i}}}{S_{\Omega_{i}}}, i=\overline{1,4}$, where $S$ is an area of the corresponding domain part; $\Omega_{i}$ is a filled part of the domain $D_{i}$.

The difference scheme for the system of equations (19) will takes the form:

- for the component $v_{r}$ :

$$
\begin{gathered}
q_{0} \frac{v_{r, i, j}^{n+1 / 2}-v_{r, i, j}^{n}}{\tau}+q_{2} \psi_{r L} \frac{v_{r, i-1, j}^{n-1 / 2}-v_{r, i-1, j}^{n-1}}{2 \tau}+q_{1} \psi_{r R} \frac{v_{r, i+1, j}^{n-1 / 2}-v_{r, i+1, j}^{n-1}}{2 \tau}+q_{1} v_{r, i+1 / 2, j}^{n} \frac{v_{r, i+1, j}^{n}-v_{r, i, j}^{n}}{4 h_{r}}+ \\
+q_{2} v_{r, i-1 / 2, j}^{n} \frac{v_{r, i, j}^{n}-v_{r, i-1, j}^{n}}{4 h_{r}}+q_{2} \psi_{r L} v_{r, i-1 / 2, j}^{n} \frac{v_{r, i, j}^{n}-v_{r, i-1, j}^{n}}{h_{r}}+q_{1} \psi_{r R} v_{r, i+1 / 2, j}^{n} \frac{v_{r, i+1, j}^{n}-v_{r, i, j}^{n}}{h_{r}}= \\
=\frac{3}{2} \mu\left(q_{1} \frac{r_{i+1} v_{r, i+1, j}^{n}-r_{i} v_{r, i, j}^{n}}{r_{i+1 / 2} h_{r}^{2}}-q_{2} \frac{r_{i} v_{r, i, j}^{n}-r_{i-1} v_{r, i-1, j}^{n}}{r_{i-1 / 2} h_{r}^{2}}\right)+q_{0} \frac{\left(v_{\theta, i, j}^{n}\right)^{2}}{2 r}+q_{0} \frac{f_{r, i, j}}{2} \\
q_{0} \frac{v_{r, i, j}^{n+1}-v_{r, i, j}^{n+1 / 2}}{\tau}+q_{4} \psi_{z L} \frac{v_{r, i, j-1}^{n}-v_{r, i, j-1}^{n-1 / 2}}{2 \tau}+q_{3} \psi_{z R} \frac{v_{r, i, j+1}^{n}-v_{r, i, j+1}^{n-1 / 2}}{2 \tau}+q_{3} v_{z, i, j+1 / 2}^{n} \frac{v_{r, i, j+1}^{n+1 / 2}-v_{r, i, j}^{n+1 / 2}}{4 h_{z}}+ \\
+q_{4} v_{z, i, j-1 / 2}^{n} \frac{v_{r, i, j}^{n+1 / 2}-v_{r, i, j-1}^{n+1 / 2}+q_{4} \psi_{z L} v_{z, i, j-1 / 2}^{n} \frac{v_{r, i, j}^{n+1 / 2}-v_{r, i, j-1}^{n+1 / 2}}{h_{z}}+q_{3} \psi_{z R} v_{z, i, j+1 / 2}^{n} \frac{v_{r, i, j+1}^{n+1 / 2}-v_{r, i, j}^{n+1 / 2}}{h_{z}}=}{4 h_{z}} \\
=\frac{3}{2} \mu\left(q_{3} \frac{v_{r, i, j+1}^{n+1 / 2}-v_{r, i, j}^{n+1 / 2}}{h_{z}^{2}}-q_{4} \frac{v_{r, i, j}^{n+1 / 2}-v_{r, i, j-1}^{n+1 / 2}}{h_{z}^{2}}\right)+q_{0} \frac{\left(v_{\theta, i, j}^{n}\right)^{2}}{2 r}+q_{0} \frac{f_{r, i, j}}{2}
\end{gathered}
$$

- for the component $v_{\theta}$ :

$$
\begin{gathered}
q_{0} \frac{v_{\theta, i, j}^{n+1 / 2}-v_{\theta, i, j}^{n}}{\tau}+q_{2} \psi_{r L} \frac{v_{\theta, i-1, j}^{n-1 / 2}-v_{\theta, i-1, j}^{n-1}}{2 \tau}+q_{1} \psi_{r R} \frac{v_{\theta, i+1, j}^{n-1 / 2}-v_{\theta, i+1, j}^{n-1}}{2 \tau}+q_{1} v_{r, i+1 / 2, j}^{n} \frac{v_{\theta, i+1, j}^{n}-v_{\theta, i, j}^{n}}{4 h_{r}}+ \\
+q_{2} v_{\theta, i-1 / 2, j}^{n} \frac{v_{\theta, i, j}^{n}-v_{\theta, i-1, j}^{n}}{4 h_{r}}+q_{2} \psi_{r L} v_{r, i-1 / 2, j}^{n} \frac{v_{\theta, i, j}^{n}-v_{\theta, i-1, j}^{n}}{h_{r}}+q_{1} \psi_{r R} v_{r, i+1 / 2, j}^{n} \frac{v_{\theta, i+1, j}^{n}-v_{\theta, i, j}^{n}}{h_{r}}=
\end{gathered}
$$




$$
\begin{gathered}
=\frac{3}{2} \mu\left(q_{1} \frac{r_{i+1} v_{\theta, i+1, j}^{n}-r_{i} v_{\theta, i, j}^{n}}{r_{i+1 / 2} h_{r}^{2}}-q_{2} \frac{r_{i} v_{\theta, i, j}^{n}-r_{i-1} v_{\theta, i-1, j}^{n}}{r_{i-1 / 2} h_{r}^{2}}\right)-q_{0} \frac{v_{\theta, i, j} v_{r, i, j}}{2 r}+q_{0} \frac{f_{\theta, i, j}}{2} ; \\
q_{0} \frac{v_{\theta, i, j}^{n+1}-v_{\theta, i, j}^{n+1 / 2}}{\tau}+q_{4} \psi_{z L} \frac{v_{\theta, i, j-1}^{n}-v_{\theta, i, j-1}^{n-1 / 2}}{2 \tau}+q_{3} \psi_{z R} \frac{v_{\theta, i, j+1}^{n}-v_{\theta, i, j+1}^{n-1 / 2}}{2 \tau}+q_{3} v_{z, i, j+1 / 2}^{n} \frac{v_{\theta, i, j+1}^{n+1 / 2}-v_{\theta, i, j}^{n+1 / 2}}{4 h_{z}}+ \\
+q_{4} v_{z, i, j-1 / 2}^{n} \frac{v_{\theta, i, j}^{n+1 / 2}-v_{\theta, i, j-1}^{n+1 / 2}}{4 h_{z}}+q_{4} \psi_{z L} v_{z, i, j-1 / 2}^{n} \frac{v_{\theta, i, j}^{n+1 / 2}-v_{\theta, i, j-1}^{n+1 / 2}}{h_{z}}+q_{3} \psi_{z R} v_{z, i, j+1 / 2}^{n} \frac{v_{\theta, i, j+1}^{n+1 / 2}-v_{\theta, i, j}^{n+1 / 2}}{h_{z}}= \\
=\frac{3}{2} \mu\left(q_{3} \frac{v_{\theta, i, j+1}^{n+1 / 2}-v_{\theta, i, j}^{n+1 / 2}}{h_{z}^{2}}-q_{4} \frac{v_{\theta, i, j}^{n+1 / 2}-v_{\theta, i, j-1}^{n+1 / 2}}{h_{z}^{2}}\right)-q_{0} \frac{v_{\theta, i, j}^{n} v_{r, i, j}^{n}}{2 r}+q_{0} \frac{f_{\theta, i, j}}{2} ;
\end{gathered}
$$

- for the component $v_{z}$ :

$$
\begin{aligned}
& q_{0} \frac{v_{z, i, j}^{n+1 / 2}-v_{z, i, j}^{n}}{\tau}+q_{2} \psi_{r L} \frac{v_{z, i-1, j}^{n-1 / 2}-v_{z, i-1, j}^{n-1}}{2 \tau}+q_{1} \psi_{r R} \frac{v_{z, i+1, j}^{n-1 / 2}-v_{z, i+1, j}^{n-1}}{2 \tau}+q_{1} v_{r, i+1 / 2, j}^{n} \frac{v_{z, i+1, j}^{n}-v_{z, i, j}^{n}}{4 h_{r}}+ \\
& +q_{2} v_{\theta, i-1 / 2, j}^{n} \frac{v_{z, i, j}^{n}-v_{z, i-1, j}^{n}}{4 h_{r}}+q_{2} \psi_{r L} v_{r, i-1 / 2, j}^{n} \frac{v_{z, i, j}^{n}-v_{z, i-1, j}^{n}}{h_{r}}+q_{1} \psi_{r R} v_{r, i+1 / 2, j}^{n} \frac{v_{z, i+1, j}^{n}-v_{z, i, j}^{n}}{h_{r}}= \\
& =\frac{3}{2} \mu\left(q_{1} \frac{r_{i+1 / 2}\left(v_{z, i+1, j}^{n}-v_{z, i, j}^{n}\right)}{r_{i} h_{r}^{2}}-q_{2} \frac{r_{i-1 / 2}\left(v_{z, i, j}^{n}-v_{z, i-1, j}^{n}\right)}{r_{i} h_{r}^{2}}\right)+q_{0} \frac{f_{z, i, j}}{2} ; \\
& q_{0} \frac{v_{z, i, j}^{n+1}-v_{z, i, j}^{n+1 / 2}}{\tau}+q_{4} \psi_{z L} \frac{v_{z, i, j-1}^{n}-v_{z, i, j-1}^{n-1 / 2}}{2 \tau}+q_{3} \psi_{z R} \frac{v_{z, i, j+1}^{n}-v_{z, i, j+1}^{n-1 / 2}}{2 \tau}+q_{3} v_{z, i, j+1 / 2}^{n} \frac{v_{z, i, j+1}^{n+1 / 2}-v_{z, i, j}^{n+1 / 2}}{4 h_{z}}+ \\
& +q_{4} v_{z, i, j-1 / 2}^{n} \frac{v_{z, i, j}^{n+1 / 2}-v_{z, i, j-1}^{n+1 / 2}}{4 h_{z}}+q_{4} \psi_{z L} v_{z, i, j-1 / 2}^{n} \frac{v_{z, i, j}^{n+1 / 2}-v_{z, i, j-1}^{n+1 / 2}}{h_{z}}+q_{3} \psi_{z R} v_{z, i, j+1 / 2}^{n} \frac{v_{z, i, j+1}^{n+1 / 2}-v_{z, i, j}^{n+1 / 2}}{h_{z}}= \\
& =\frac{3}{2} \mu\left(q_{3} \frac{v_{z, i, j+1}^{n+1 / 2}-v_{z, i, j}^{n+1 / 2}}{h_{z}^{2}}-q_{4} \frac{v_{z, i, j}^{n+1 / 2}-v_{z, i, j-1}^{n+1 / 2}}{h_{z}^{2}}\right)+q_{0} \frac{f_{z, i, j}}{2} .
\end{aligned}
$$

The difference scheme for the calculation of pressure will takes the form:

$$
\begin{gathered}
q_{0} r_{i} \frac{P_{i, j}^{n+1} /(\varepsilon T)_{i, j}^{n+1}-P_{i, j}^{n} /(\varepsilon T)_{i, j}^{n}}{\tau}+q_{1} \frac{r_{i+1} \tilde{v}_{r, i+1, j}^{n} \rho_{i+1, j}^{n}-r_{i} \tilde{v}_{r, i, j}^{n} \rho_{i, j}^{n}}{2 h_{r}}+ \\
+q_{2} \frac{r_{i} \tilde{v}_{r, i, j}^{n} \rho_{i, j}^{n}-r_{i-1} \tilde{v}_{r, i-1, j}^{n} \rho_{i-1, j}^{n}}{2 h_{r}}+q_{3} r_{i} \frac{\tilde{v}_{z, i, j+1}^{n} \rho_{i, j+1}^{n}-\tilde{v}_{z, i, j}^{n} \rho_{i, j}^{n}}{2 h_{z}}+ \\
+q_{4} r_{i} \frac{\tilde{v}_{z, i, j}^{n} \rho_{i, j}^{n}-\tilde{v}_{z, i, j-1}^{n} \rho_{i, j-1}^{n}}{2 h_{z}}=q_{1} \tau \frac{r_{i+1 / 2}\left(P_{i+1, j}^{n}-P_{i, j}^{n}\right)}{h_{r}^{2}}-q_{2} \tau \frac{r_{i-1 / 2}\left(P_{i, j}^{n}-P_{i-1, j}^{n}\right)}{h_{r}^{2}}+ \\
+q_{3} \tau r_{i} \frac{P_{i, j+1}^{n}-P_{i, j}^{n}}{h_{z}^{2}}-q_{4} \tau r_{i} \frac{P_{i, j}^{n}-P_{i, j-1}^{n}}{h_{z}^{2}} .
\end{gathered}
$$

The difference schemes for the system of equations (22) will takes the form:

$$
q_{0} \frac{\hat{v}_{r, i, j}-\tilde{v}_{r, i, j}}{\tau}=-q_{1} \frac{P_{i+1, j}^{n+1}-P_{i, j}^{n+1}}{2 \rho h_{r}}-q_{2} \frac{P_{i, j}^{n+1}-P_{i-1, j}^{n+1}}{2 \rho h_{r}},
$$




$$
q_{0} \frac{\hat{v}_{z, i, j}-\tilde{v}_{z, i, j}}{\tau}=-q_{3} \frac{P_{i, j+1}^{n+1}-P_{i, j}^{n+1}}{2 \rho h_{z}}-q_{4} \frac{P_{i, j}^{n+1}-P_{i, j-1}^{n+1}}{2 \rho h_{z}} .
$$

Software implementation. The initial parameters of the model are: the rotation frequency of the turbine; the range of exit velocities at the turbine blades; the number of blades; the number of nozzle channels; the width of the nozzle channel to the impeller; the steam pressure on impellers.

The speed of steam movement is indicated by the color. The measure units is meters per second. Due to the developed software, we can calculate movement of the operating environment within areas with cylindrical symmetry and determine the velocity and pressure field patterns within axial steam turbines. The permeability of the medium was used in the mathematical model for describing the geometry of the nozzle lattice. The movement of steam in several stages at the same time can be calculated on the basis of the developed software. The distribution fields of the main physical computing quantities inside for the first operating chamber are shown in Fig. 2 (1 is the longitudinal and radial component of the velocity vector, $\mathrm{m} / \mathrm{sec} ; 2$ is the rotation speed, revs/min; 3 is the pressure, atm.; 4 is the turbulent viscosity, Pa.sec; 5 is the temperature, ${ }^{\circ} \mathrm{C} ; 6$ is the density, $\mathrm{kg} / \mathrm{m}^{3}$ ).
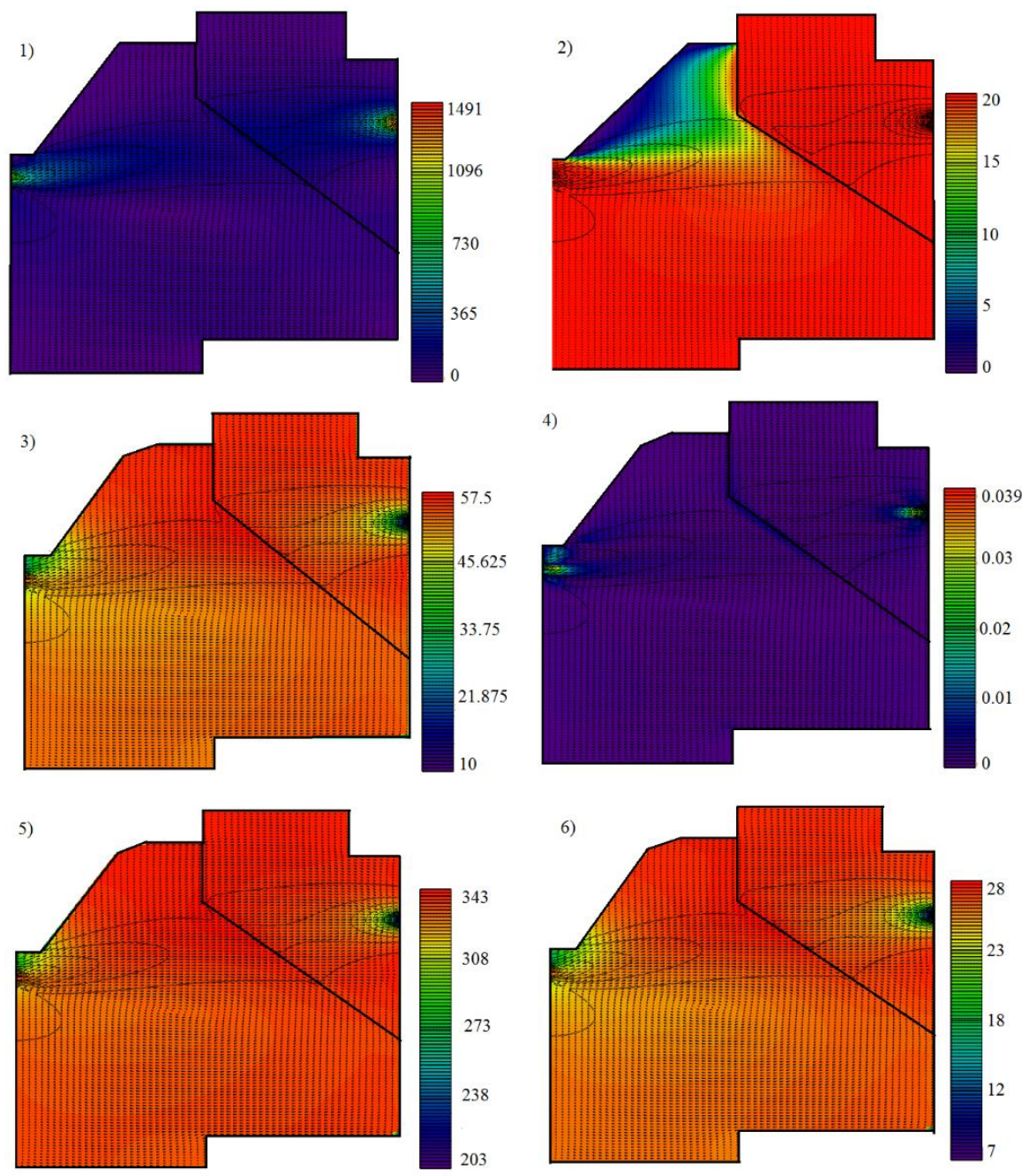

Fig. 2. Distribution fields of the main physical computing quantities inside for the first operating chamber 
Conclusion. The mathematical model of gas-dynamic processes in a steam turbine was developed. The main equations of the model are the Navier-Stokes equations, the continuity and condition equations for the real gas. The initial system of equations was written in a cylindrical coordinate system taking into account the axial symmetry of the steam flow field in the turbine. The splitting schemes into physical processes (the pressure correction method) were used for approximation problem in the temporary variable. According to this method, the problem is solved in three stages. The diffusion-convection equation with large Peclet numbers is necessary for calculating the velocity field components without taking into account the pressure. New difference schemes, based on the «cabaret» scheme modernization, were applied for solving this problem. These difference schemes are in 2-2.5 times more accurately solve the diffusion-convection problem in comparison with traditional «cabaret» schemes, which are effective in solving such problems. Software implementation of the problem was performed on the basis of the devel-oped algorithms, and the results of numerical calculations of aerodynamic processes in the steam turbine were obtained.

\section{References}

1. Samarsky A.A., Nikolaev E.S. Methods of solving grid equations. - M.: Science, 1978. - 588 p.

2. Sukhinov A.I., Chistyakov A.E. Adaptive modified alternating triangular iterative method for solving grid equations with non-selfadjoint operator // Mathematical modeling. - 2012. - Vol. 24, № 1. - pp. 3-20.

3. Konovalov A.N. The method of steepest descent with adaptive alternately-triangular preamplification // Differential equations. - 2004. - Vol. 40, № 7. - pp. 953.

4. Konovalov A.N. The theory of alternating-triangular iterative method // Siberian mathematical journal. - 2002. - Vol. 43, № 3. - pp. 552.

5. Sukhinov A.I., Chistyakov A.E., Shishenya A.V. Error Estimate of the solution of the diffusion equation on the basis of the schemes with weights // Mathematical modeling. - 2013. - Vol. 25, № 11. - pp. 53-64.

6. Sukhinov A.I., Chistyakov A.E., Fomenko N.A. Methods of constructing difference schemes for the problem of diffusion-convection-reaction, taking into account the occupancy level of the control cells // Izvestiya SFedU engineering sciences. - 2013. № 4. - pp. 87-98.

7. Samarskiy A.A. Theory of difference schemes. M. Nauka. 1989.

8. Samarskiy A.A., Gulin A.V. Numerical methods. M.: Nauka. 1989.

9. Beklemishev K.A., Petrov I.B., Favorsky A.V. Numerical simulation of processes in rigid deformable media in the presence of dynamic contacts using grid-characteristic method // Mathematical modeling. 2013. - Vol. 25, № 11. - pp. 3-16.

10. Petrov I.B., Favorsky A.V., Sannikov A.V., Kvasov I.E. Grid-characteristic method using high order interpolation on tetrahedral hierarchical meshes with a multiple time step // Mathematical modeling. - 2013. - Vol. 25, № 2. - pp. 42-52.

11. Sukhinov A.I., Chistyakov A.E., Semenyakina A.A., Nikitina A.V. Parallel realization of the tasks of the transport of substances and recovery of the bottom surface on the basis of schemes of high order of accuracy // Computational methods and programming: new computing technology. 2015. - Vol. 16, № 2. - pp. 256-267. 
12. Nikitina A.V., Semenyakina A.A., Chistyakov A.E., Protsenko E.A., Yakovenko I.V. Application of schemes of increased order of accuracy for solving problems of biological kinetics in a multiprocessor computer system // Fundamental research. - 2015. № 12-3. - pp. 500-504.

13. Chistyakov A.E., Hachunts D.S., Nikitina A.V., Protsenko E.A., Kuznetsova I.Yu. Parallel Library of iterative methods of the SLAE solvers for problem of convection-diffusion-based decomposition in one spatial direction // Modern problems of science and education. - 2015. - № 11. - pp. 1786.

14. Sukhinov A.I., Nikitina A.V., Semenyakina A.A., Protsenko E.A. Complex programs and algorithms to calculate sediment transport and multi-component suspensions on a multiprocessor computer system // Engineering journal of Don. - 2015. - Vol. 38, № 4 (38). - pp. 52.

15. Nikitina A.V., Abramenko Y.A., Chistyakov A.E.: Mathematical modeling of oil spill in shallow waters // Informatics, computer science and engineering education. - 2015. - № 3 (23). - pp. 49-55.

16. Chistyakov A.E., Nikitina A.V., Ougolnitsky G.A., Puchkin V.M., Semenov I.S., Sukhinov A.I., Usov A.B. A differential game model of preventing fish kills in shallow waterbodies // Game Theory and Applications. - 2015. - Vol. 17. - pp. 37-48.

17. Sukhinov A.I., Nikitina A.V., Semenyakina A.A., Chistyakov A.E. A set of models, explicit regularized schemes of high order of accuracy and programs for predictive modeling of consequences of emergency oil spill // Parallel computational technologies (PCT 2016) proceedings of the international scientific conference. - 2016. - pp. 308-319.

18. Chistyakov A.E., Nikitina A.V., Sumbaev V.V. Solution of the Poisson problem based on the multigrid method // Herald of computer and information technologies. - 2016. - № 8 (146). - pp. 37.

19. Nikitina A.V., Semenyakina A.A., Chistyakov A.E. Parallel implementation of the tasks of diffusion-convection-based schemes of high order of accuracy // Herald of computer and information technologies. - 2016. № 7 (145). - pp. 3-8.

20. Sukhinov A.I., Chistyakov A.E., Semenyakina A.A., Nikitina A.V. Numerical modeling of an ecological condition of the Sea of Azov with application of schemes of the raised accuracy order on the multiprocessor computing system // Computer researches and modeling. - 2016. - Vol. 8, № 1. pp. 151-168.

21. Sukhinov A.I., Nikitina A.V., Semenyakina A.A., Chistyakov A.E. Complex of models, explicit regularized schemes of high-order of accuracy and applications for predictive modeling of after-math of emergency oil spill/CEUR Workshop Proceedings. - Vol. 1576. - pp. 308-319.

22. Nikitina A.V., Sukhinov A.I. Ougolnitsky G.A., Usov A.B., Chistyakov A.E., Puchkin M.V., Semenov, I.S. Optimal management of sustainable development at the biological rehabilitation of the Azov Sea // Mathematical modeling. - Vol. 28, № 7. - pp. 96-106. 
Authors:

Sukhinov Alexander Ivanovich, Don State Technical University (1st Gagarin Square, Rostov-onDon, Russian Federation), Doctor of Science in Physics and Maths, Professor

Chistyakov Alexander Evgenievich, Don State Technical University (1st Gagarin Square, Rostovon-Don, Russian Federation), Doctor of Science in Physics and Maths, Associate professor

Yefimov Nikolay Nikolayevich, Federal State Budget Educational Institution of Higher Education Platov South-Russian State Polytechnic University (NPI) (132, Prosveshcheniya, Novocherkassk, Rostov Region, Russian Federation), Doctor of technical science, Associate professor

Baltan Vasily Nikolaevich, Federal State Budget Educational Institution of Higher Education Platov South-Russian State Polytechnic University (NPI) (132, Prosveshcheniya, Novocherkassk, Rostov Region, Russian Federation), Doctor of technical science, Associate professor 


\section{Математическая модель газодинамических и тепловых процессов в паровой турбине *}

\section{А.И. Сухинов, А.Е. Чистяков ${ }^{* *}$, Н.Н. Ефимов, В.Н. Балтян ${ }^{* * *}$}

Донской государственный технический университет, Ростов-на-Дону, Российская Федерация Южно-Российский государственный политехнический университет (НПИ) имени М.И. Платова, Новочеркасск, Российская Федерация

В работе представлен расчет аэродинамических процессов в паровой турбине с использованием современных информационных технологий и вычислительных методов повышения точности расчетов. Практическая значимость работы заключается в следующем: разработана и реализована модель аэродинамических процессов в паровой турбине, определены пределы и перспективы предложенной математической модели. Аэродинамические процессы в турбине характеризуются неравномерностью паровых и тепловых потоков, что существенно влияет на надежность и эффективность работы турбины. Расчет выполнен с учетом сложной геометрии турбины и может быть применен к любой турбине аналогичной конструкции с незначительными изменениями.

Ключевые слова: математическая модель, аэродинамика, паровая турбина, вычислительные эксперименты, паровые и тепловые потоки

\section{Авторы:}

Сухинов Александр Иванович, Донской государственный технический университет (344000 Ростов-на-Дону, пл. Гагарина, д. 1), доктор физико-математических наук, профессор

Чистяков Александр Евгеньевич, Донской государственный технический университет (344000 Ростов-на-Дону, пл. Гагарина, д. 1), доктор физико-математических наук, доцент

Ефимов Николай Николаевич, Федеральное государственное бюджетное образовательное учреждение высшего образования «Южно-Российский государственный политехнический университет (НПИ) имени М.И. Платова» (346428, Ростовская обл., г. Новочеркасск, ул. Просвещения, 132), доктор технических наук, профессор

Балтян Василий Николаевич, Федеральное государственное бюджетное образовательное учреждение высшего образования «Южно-Российский государственный политехнический университет (НПИ) имени М.И. Платова» (346428, Ростовская обл., г. Новочеркасск, ул. Просвещения, 132), доктор технических наук, профессор

\footnotetext{
* Работа выполнена в рамках соглашения с Министерством образования и науки Российской Федерации. № 14.577.21.0260 о предоставлении субсидий с 26.09.2017 года по Федеральной целевой программе «Научные исследования и разработки по приоритетным направлениям развития научно-технологического комплекса России на 2014-2020 годы».

**E-mail: sukhinov@gmail.com, cheese_05@mail.ru.

*** E-mail: efimov@ novoch.ru.
} 